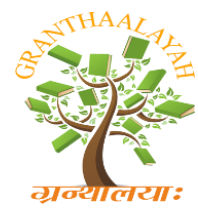

INTERNATIONAL JOURNAL OF RESEARCH GRANTHAALAYAH

A knowledge Repository

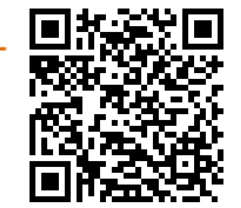

Management

\title{
SUPPLY CHAIN MANAGEMENT OF INDIAN ENTERPRISE IN INTERNATIONAL OPERATIONS: TYPE OF MODERN LITERARY CRITIQUE
}

\author{
Deepak Hajoary ${ }^{* 1}$ \\ ${ }^{* 1}$ Department of Management Studies, Bodoland University, Kokrajhar, Assam, INDIA
}

\begin{abstract}
This paper aims to explore supply chain management challenges and prospects in the international scenario. Globalization has delivered a platform for local companies to think at international level. The paper will highlights different critical scenarios of supply chain management. The study will identify key strategies that can be constructed at global supply chain. Issues of supply chain design, tools and sourcing strategy will be studied in the paper.
\end{abstract}

Keywords:

Supply chain management, international operation, value chain.

Cite This Article: Deepak Hajoary, "SUPPLY CHAIN MANAGEMENT OF INDIAN ENTERPRISE IN INTERNATIONAL OPERATIONS: TYPE OF MODERN LITERARY CRITIQUE” International Journal of Research - Granthaalayah, Vol. 4, No. 3 (2016): 107-118.

\section{INTRODUCTION}

Supply chain management focus on optimization of cost, speed and delivery at the right time to right customers. Enterprises have to adjust logistics operations to meet customer's service. In the rapid development of economy, the collaboration and coordination are critical factor for achieving success for an organization. The key success of Indian enterprises is developing close relationship of trust and building its supplier agents long term relationship. Supply chain management has gained much importance in the $21^{\text {st }}$ century. For organization going global is not so easy as it seems. There are several unpredictable challenges it can face in the road ahead. American Production and Inventory Control (APICS, 1990) defined supply chain as the process from raw material to final customers including all its constituents parts.

\section{DEFINITION OF SUPPLY CHAIN MANAGEMENT}

\begin{tabular}{|l|l|}
\hline $\begin{array}{l}\text { Bowersox et } \\
\text { al., 2010, p.4 }\end{array}$ & $\begin{array}{l}\text { "Supply chain management consists of firms collaborating to leverage strategic } \\
\text { Positioning and to improve operating efficiency. For each firm involved, the } \\
\text { supply Chain relationship reflects a strategic choice." }\end{array}$ \\
\hline Chopra and & "Effective supply chain management involves the management of supply chain \\
\hline
\end{tabular}




\begin{tabular}{|l|l|}
\hline $\begin{array}{l}\text { Meindl, 2007, } \\
\text { p. } 6\end{array}$ & $\begin{array}{l}\text { assets and product, information, and fund flows to maximize total supply chain } \\
\text { profitability." }\end{array}$ \\
\hline $\begin{array}{l}\text { Gibson } \text { et al., } \\
\text { G05, p. }\end{array}$ & Gibson et al., 2005 \\
\hline $\begin{array}{l}\text { Harrison and } \\
\text { van Hoeck, } \\
\text { "S08, p. 6 }\end{array}$ & $\begin{array}{l}\text { "Supply chain management: Planning and controlling all of the business } \\
\text { partners in a supply chain in order to serve the needs of the end-customer." }\end{array}$ \\
\hline $\begin{array}{l}\text { Lummus and } \\
\text { Vokurka, }\end{array}$ & $\begin{array}{l}\text { "All the activities involved in delivering a product from raw material through } \\
\text { to the customer including sourcing raw materials and parts, manufacturing and } \\
\text { assembly, warehousing and inventory tracking, order entry and order } \\
\text { management, distribution across all cannels, delivery to the customer and the } \\
\text { information systems necessary to monitor all of these activity of these } \\
\text { activities into a seamless process. It links all of the partners in the chain } \\
\text { including departments within an organization and the external partners } \\
\text { including }\end{array}$ \\
\hline McLaren et al & $\begin{array}{l}\text { "involves the coordination of an organization's internal planning, } \\
\text { manufacturing, and procurement efforts with those of its external partners". }\end{array}$ \\
\hline $\begin{array}{l}\text { Simchi-Levi } \text { et } \\
\text { al. (2008) }\end{array}$ & $\begin{array}{l}\text { "Supply chain management is a set of approaches utilized to efficiently } \\
\text { integrate suppliers, manufacturers, warehouses, and stores, so that merchandise } \\
\text { is produced and distributed at the right quantities, to the right locations, and at } \\
\text { the right time, in order to minimize system wide costs while satisfying service } \\
\text { level requirements" }\end{array}$ \\
\hline
\end{tabular}

\section{LITERATURE REVIEW}

\section{GLOBAL SUPPLY CHAIN}

Global supply chain management (GSCM) has become one of the areas of discussion due to free trade area and trade agreement between different countries. Most companies had achieved success due to first mover advantage and tapping the very nature of critical potential markets although discussion has been done on supply chain at international arena, less has been highlighted about problems of developing countries (Msimangira \& Tesha, 2009).Global suppliers need to identify their trade zone and areas it can serve their customers. The reason for some companies going global is due to its structure in business organization. Companies have found out countries where they can set up manufacturing base and serve customers. Low cost operations and feasible region with customer base are crucial factors for setting manufacturing plant. The emergence of global platform has enabled companies to think their supply chain strategy. The factors that drive companies to go global according to Dornier et al. are:

- Global market forces,

- Technological forces,

- Global cost forces,

- Political and economic forces.

Gereffi et al., 2005 stated that companies faced stiff competition and pressures from manufacturers and customers. Gereffi, 1999 concludes that companies are acquiring new technology and cutting cost to get more hold in the market. Globalization has paved the way for serving global customers on a global platform and earning more profit for the organization. But 
the challenges it faces can't be rule out. The active members of supply chain network have to manage related task like tariffs of specific country, currency and income tax. The growth of global supply chain is being studied by various researchers and academicians. Success of global supply chain depends on various critical factors. The nature of integration is very important decision in global supply scenario

\section{DOMESTIC AND GLOBAL SUPPLY CHAIN}

The major differences between domestic and global supply chain are highlighted below.Global supply chain and domestic supply chain scenerios are very complex and different.There are enormous reason to cite the reasons of difference between them. The people involved in the complex supply chain activities are also different.Some the the critical factors to differentiate between the two are given below:

\begin{tabular}{|l|l|}
\hline DOMESTIC SUPPY CHAIN & GLOBAL SUPPLY CHAIN \\
\hline Supplies within the country & International supply chain \\
\hline Less supply chain risk & Very high rate of supply chain risk \\
\hline Less supply chain security issues & High risk security issues \\
\hline Less issues on payment terms & $\begin{array}{l}\text { Issues regarding payment of international } \\
\text { suppliers and vendors }\end{array}$ \\
\hline $\begin{array}{l}\text { Regulatory issues can be less as it operates } \\
\text { within the country }\end{array}$ & Regulatory issues are very complex \\
\hline Supplier selection is easy process & $\begin{array}{l}\text { Supplier selection is difficult } \\
\text { Mode of payment is easy }\end{array}$ \\
\hline
\end{tabular}

\section{DRIVERS OF SUPPLY CHAIN MANAGEMENT}

Drivers are very important points in the supply chain management .This drivers communicate with each other in the supply chain performance. The cross functional performance of each driver is very critical for supply chain responsive performance. The functions of supply chain drivers are cited below:

\begin{tabular}{|l|l|l|}
\hline S1. & Supply chain Drivers & Functions \\
\hline 1 & Facilities & Facilitates inventory supply from its location \\
\hline 2 & Inventory & $\begin{array}{l}\text { To meet demand and supply in the supply } \\
\text { chain }\end{array}$ \\
\hline 3 & Transportation & Reduces efficiency, faster delivery of items \\
\hline 4 & Information & $\begin{array}{l}\text { Facilitates transparency and communication } \\
\text { among drivers in the supply chain }\end{array}$ \\
\hline 5 & Sourcing & Decides when to source. \\
\hline 6 & Pricing & Firm build its competitive strategy \\
\hline
\end{tabular}




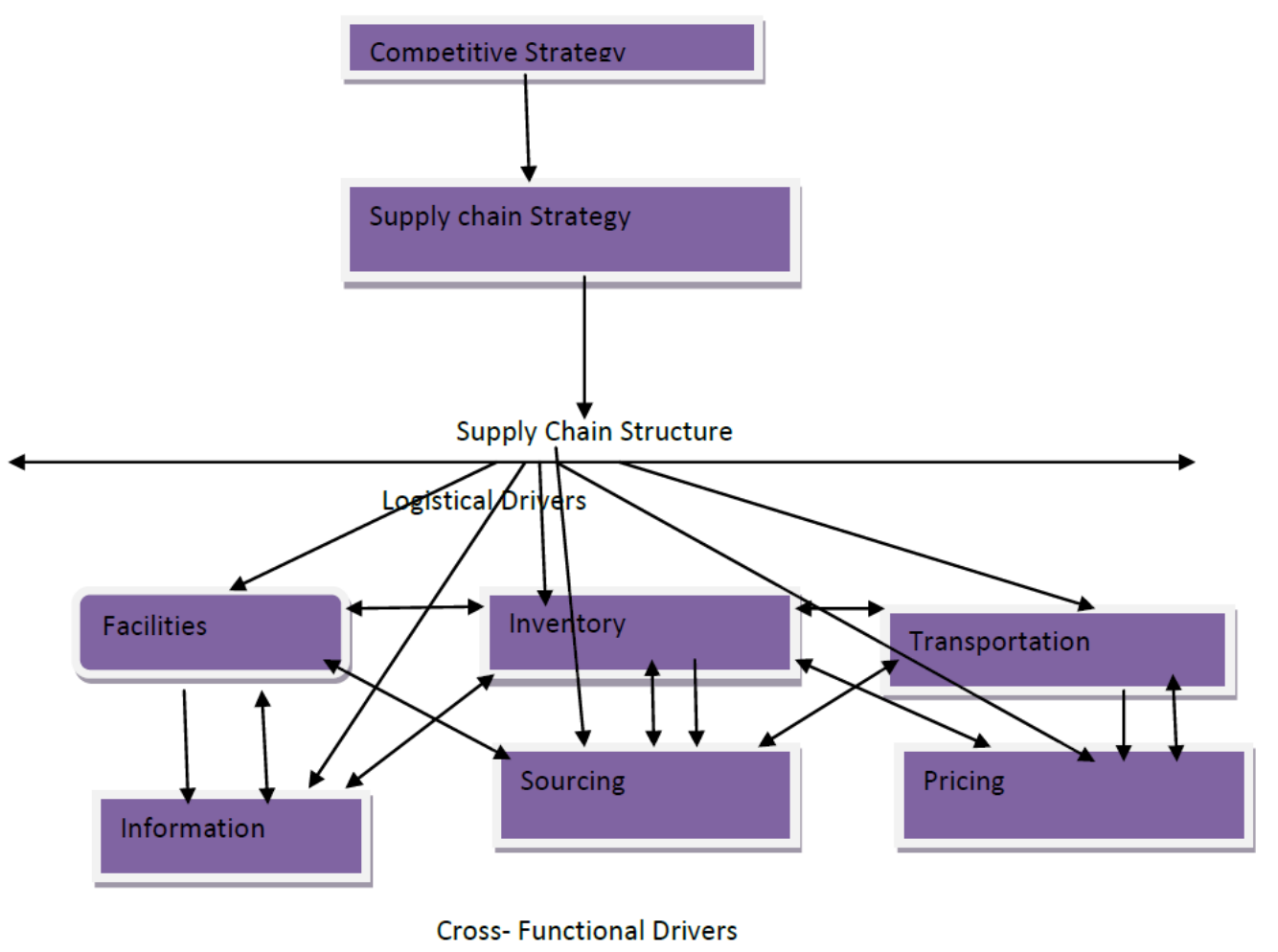

Figure 1: Drivers of supply chain

\section{DESIGNING GLOBAL SUPPLY CHAIN OPERATIONS}

With decrease in tariffs and trade contract among countries, a company can set up international operation in one country and expand it globally. With the increase of international supply chain, companies can take advantage of low cost operations and set it as manufacturing facility. The global supply chain creates opportunities for many countries and creates complex problem in the supply chain management process. Distribution refers to movement of goods from supplier to customer in the supply chain management. Dell directly distributes to customers, HP distributes through resellers. The components of customer service are

- Response time

- Product variety

- Product availability

- Customer experience

- Time to market

- Order visibility

- Return ability

Harrison (2001) had given several criteria for designing global supply chain like uncertainity and service goals. Kouvelis \& Su (2005) highlighted the following criteria for global supply chain design

i. Factories locations,

ii. Allocation of production to the various factories,

iii. How to develop suppliers for the plant, 
iv. How to manage the distribution of products,

v. How to organize the interfaces along the global supply

(Shi and Gregory, 1998) stated that global production which is also referred to as process of transforming business from local to global market place.For designing global supply chain, network configuration and coordination decision are most crucial parameter

\section{FACTORS AFFECTING GLOBAL SUPPLY CHAIN OPERATIONS}

There are numerous factors affecting supply chain management but the following are the major factors for global supply chain management.

(a) Culture barriers

This arises in global operations. A company can't function in another country affecting culture of another country.

(b) Language Barriers

It can affect in global supply chain management. The staff involve in supply chain can must able to know overcome language barriers. This can become very crucial and decision making for organization to operate in international market place.

(c) Infrastructure

For a company to be in international arena, infrastructure plays a major role. It affects operations in a global platform. The company may not locate its business in certain environment where its infrastructure is lacking behind other countries.

(d) Cost

Low cost operation is one of the significant reasons for any company to operate in international platform. A company can make that particular country its manufacturing plant and make it as supplier base serving that country and its suppliers.

(e) Technological challenge

Technology is one the reason for in global supply chain management.

Company can build its competitive edge without upgrading its technology. The technology is important in global business for holding edge over its competitors. To build a world class manufacturing product, technology can play a major role.

(f) Location Constraints

A company can find low cost operations for building its manufacturing plant but location becomes a constraint for the company. A company would have to incur great cost in supply chain management if location becomes a major constraint and might not set up its facility in that location. The right location has to suits in global supply chain management strategy. Multinational companies may employ their own staff for in-house procurement while others employ commercial agents. 
(g) Political factors

Political stability becomes an issue in international supply chain management. The instability of any region would not welcome any company to build its manufacturing facility or operate in that country. Political instability can be disruption to any company if it operates in that country.

(h) Trade Barriers

Where there is trade restriction in any country. Some country may not favor global operations. Such barriers of entry possess challenges in global supply chain management.

(i) Sustainability

A company must able to sustain in the global operations. If it can't sustain then it becomes issues for its supply chain partners.

(j) Quality

The type of quality of service it provides becomes an international issue in global supply chain management. In competing international market, quality is important from customer points of view.

(k) Information Sharing

The way information is exchanged hampers international supply chain. The lack of information exchanging can be big problem for any company. The misuses of information can delays of products in any part of the country.

(1) Cross Border issues

The way business is being done in international market is a complex issue relating to cross border. The service of one country may not be favorable to other country.

(m) Cost

This is one of the supply chain considerations by multinational companies (MNC) for locating a country to set its facility. Since the cost are rising, labour cost, supply chain cost and taxation has to be source of competitive advantage for any multinational companies .the dimensions of global supply chain management has to be priority for any multinational companies

(n) Warehousing

The type of places warehouses is set up is a factor for discussion. Warehousing strategy is important in supply chain management. It is distribution center for suppliers. Proximity to suppliers and market is critical dimension for warehouse management

(o) Supplier fraud

The type of supplier in global platform is a critical decision for management. There are many countries where companies can't operate due to supplier's fraud. There has to supply chain mechanism to detect suppliers fraud. 
(p) Payment methods

The way payment is being accepted at internal platform is a big worry for supply chain management. The currency fluctuation becomes a complex problem for global supply chain management. The type of payment term may not be same for particular region.

(q) Organizational model

Managing human resource at global platform is an issue. To find qualified professional and allocate in that region itself is a complex issues to management. The type of people employed can't be trusted and their performance has to be judged.

(r) Manufacturing challenges

The company can have manufacturing plants at different countries and the coordination among different global plants is necessary for smoothly function of its operations. The lack of information sharing among different plants can loss its global customers and suppliers.

(s) Distribution challenges

Distribution of products can be very difficult in some countries' will depends on infrastructure of specific country. There are cases where a company has to shift its manufacturing plant due to distribution challenges it possess in that country

\section{A. MANUFACTURING STORAGE WITH DIRECT SHIPPING}

Drop-shipping happens in this model of distribution. The product is shipped directly to the customer without retailer. Able to centralize inventories in the manufacture is one the advantage in this category.

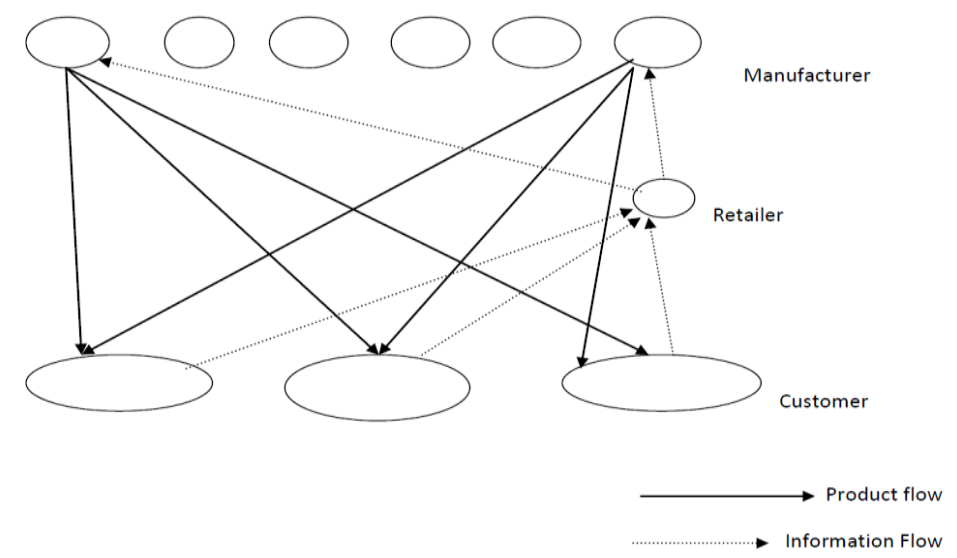

Figure 2: Manufacturing storage with direct shipping

Table 1: Performance Characteristics with manufacturing storage with direct shipping

\begin{tabular}{|l|l|}
\hline Cost Factor & Performance \\
\hline Inventory & Reduces cost due aggregation \\
\hline Transportation & Cost are very high due to distance factor \\
\hline Information & Integration is crucial in information sharing \\
\hline Facilities and handling & Aggregation reduces lower facility cost \\
\hline
\end{tabular}




\begin{tabular}{|l|l|}
\hline \multicolumn{2}{|l|}{} \\
\hline Service factor & Performance \\
\hline Response time & Duration of response time is long \\
\hline Product variety & Very easy to offer product variety \\
\hline Time to market & Can deliver very fast \\
\hline Customer experience & For customer its good but problem in partial shipment \\
\hline
\end{tabular}

\section{B. MANUFACTURER STORAGE WITH DIRECT SHIPPING AND IN-TRANSIT MERGE}

\section{In this model order is delivered to single customer.}

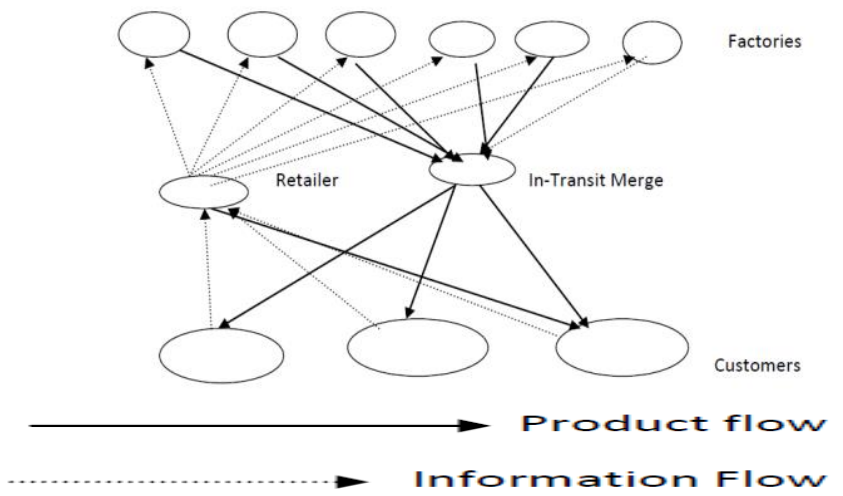

Figure 3: manufacturer storage with direct shipping and in-transit merge

Table 2: Performance Characteristics with manufacturing storage with direct shipping

\begin{tabular}{|l|l|}
\hline COST FACTOR & PERFORMANCE \\
\hline Inventory & Same as drop-shipping \\
\hline Transportation & Lower cost than drop shipping \\
\hline Information & Investment cost is slightly higher than other models \\
\hline Facilities and handling & Cost is higher than other model \\
\hline \multicolumn{2}{|l}{} \\
\hline SERVICE FACTOR & PERFORMANCE \\
\hline Response time & Same as drop shipping \\
\hline Product variety & Same as drop shipping \\
\hline Time to market & Same as drop shipping \\
\hline Customer experience & Better than drop shipping method \\
\hline
\end{tabular}

\section{ISSUES OF SUPPLY CHAIN IN INDIA}

There can be numerous issues in supply chain activities. The type of issues can't be neglected in supply chain procees rather it has to be analyzed to solve the issues. 
Table 3: Issues of supply chain

\begin{tabular}{|l|l|}
\hline Taxation & $\begin{array}{l}\text { Policies of less tax in certain location of setting manufacturing } \\
\text { plant } \\
\text { Special economic zone offer tax benefits for companies }\end{array}$ \\
\hline Logistics infrastructure & $\begin{array}{l}\text { Poor infrastructure of sustaining supply chain by Indian } \\
\text { companies }\end{array}$ \\
\hline Global connectivity & Need to increase connectivity of its chain at international platform \\
\hline Demanding customers & Numerous types of customers \\
\hline Supply and demand & Unable to meet supply and demand of Indian market \\
\hline Security of supply chain & Risk in security of supply chain \\
\hline Bandh culture & Affects supply chain to deliver within lead time provided \\
\hline Supply chain risk & $\begin{array}{l}\text { Unavoidable supply chain risk in India. Risk of anti social } \\
\text { activities of doing business }\end{array}$ \\
\hline Supplier risk & Very difficult to find type of supplier with good track record. \\
\hline Transportation & $\begin{array}{l}\text { Infrastructure problem in current Indian scenario. Unable to } \\
\text { transport in some regions of India }\end{array}$ \\
\hline
\end{tabular}

\section{SUPPLY CHAIN MECHANISMS OF INDIAN ENTERPRISE}

The integration of information technology in supply chain management is very important for smooth flow of its activities in the cycle of supply process. For any business enterprise delivering profit and customer success criteria is vital. The international operation of supply chain mechanisms of Indian enterprises has some important points based on current scenario

A. The supply chain process is continuous, systematic and integrated process.

The coordination of all the participants in the supply chain process is crucial factor. The relationship has to be to serve customer satisfaction. The link from top to bottom has to be dynamic and smooth flow of information without any bottleneck in the system. The bottleneck can delay the system and problem can occur. The whole participant in the supply chain network has to deliver smooth flow of information

B. Win to serve is the strategy in international supply chain operations Other than logistics flows, value added flows is important in international supply chain operations.Th steps of supply chain adds value to the customer. The competence of enterprise is based on its value adding activity. The integration of all its functions is important to determine optimization cost associated with the supply chain activities. The mechanism is to achieve low cost operations and better relation with its supply chain partners.

\section{Co-ordination in supply chain management and well defined objective in mind}

To achieve successful supply chain operations in the international market, close coordination is very essential in the chain activities. The objective of the enterprises has to be well defined and there may be parties who may win or lose in the process. 
D. Supply chain network and information sharing are two most vital factors of international operations

Information sharing is a new tool in the supply chain management and foundation of its international operations. The network can easily describe the process of value adding activities

\section{THE CONSTRUCTION OF ENTERPRISE GRADE SUPPLY CHAIN MANAGEMENT AS IT ENTERED INTERNATIONAL BORDER}

The following points has to be considered while constructing supply chain across border.

a. The purpose and benefit of each party has to be analyzed

b. Analyze each success factor for each enterprise

c. Need to identify sustainability factor for enterprise

d. Detect early problem in supply chain management.

e. Understand the position of itself in international market and make outsource as it strategy when needed.
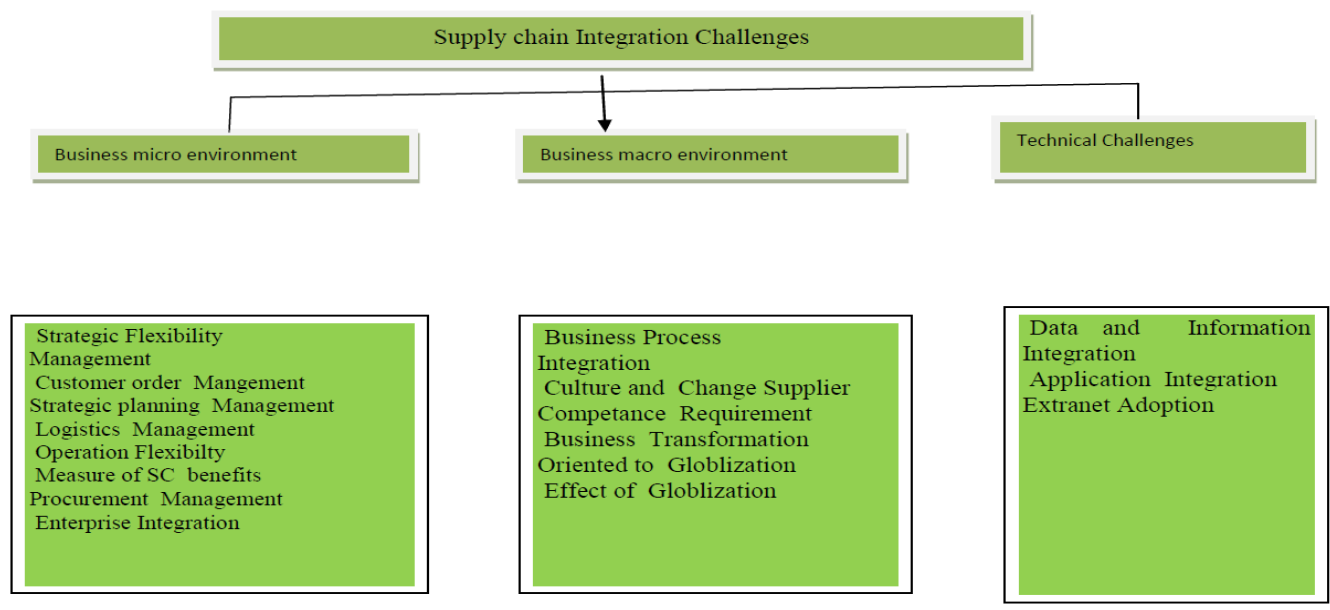

Figure 4: Supply Chain Management: Some Issues and Challenges - A Review

\section{GLOBAL SUPPLY CHAIN OPERATIONS STRATEGES AND OPPORTUNITIES}

For entering emerging markets, companies have to adopt the following strategies.

1. Analyze the strategic position of the enterprise, positions in the country, suppliers and predict uncertain factors that can arise

2. Make necessary changes in the strategy of supply chain management

3. Decision making to be centralized pr decentralized based on the market requirement and type of country it's located

4. Learn from global leaders in the leading global supply chain management

5. Integrate low cost manufacturing plant into global supply chain management and operates in dual modes operation. Supports sales in that specific country and make it as global operation by producing in that country and export to other country. 
6. Use modern technology when the product is outdated and integrate information technology into various departments of global supply chain management for fast information sharing

7. Optimize supply chain out of manufacturing plant where it's located.

8. In the global supply chain management, multinational companies have to verify whether global suppliers are aligned with its company's policy and sustainability agenda.

9. Analyze the market potential and check sustainability criteria of that country.

10. Low cost producer is one of the strategies in global market.

11. Focus on customer satisfaction of regions globally.

12. International companies have to adopt off shoring and re-shoring strategy.

13. Risk mechanism is very essential for mitigating risk in global supply chain management.

14. Adoption of supply chain security measures.

15. Adoption of technology to meet supply and demand in the global market place

\section{CONCLUSIONS}

Global supply chain management are very complex as it involves numerous channels. The risk involves are high and it needs to be analyzed and prior initiative has to be formalized to mitigate risk. For any International companies, the operations can't be smooth flow as it consists of people mindset around the corner of the world. It is significant factors for any multinational companies entering emerging markets anywhere in the world to face problems every time and in any parts of the business. There is always a scope of future research to study the scenarios that can and will surely compel any researcher to analyze the future prospects angle of global supply chain management

\section{REFERENCES}

[1] Adebambo, Somuyiwa(2013), Firm's Competitiveness through Supply Chain Responsiveness and Suppl Chain Management Practices in Nigeria, Journal of Poverty, Investment and Development, Vol.1 Pg no. 142-147

[2] Ramma Reddy,M.Venkatta(2012), "Status of Supply chain in India", International journal of emerging Technology and advanced engineering,Vol.2,Issue 7,Pg 429-431

[3] Vieira Conceição,Samuel and C. de Sá Gazolla,Eduardo,Global Supply Chain Management in Emerging Markets Global Supply Chain, Proceedings of the Twelfth Annual Conference of the Production and Operation Management Society POM-2001, March 30 - April 2, 2001, Orlando FL

[4] Giminez.Cristina,Sancha.Cristina and Mendoza.Xavier, Global Supply Chain

[5] Burgess K., Singh P.J., A proposed integrated framework for analysing supply chains. Supply Chain Management: An International Journal, Vol. 11, issue 4, 2006

[6] http://www.epiqtech.com/supply_chain-Global-Management.htm

[7] Gereffi, G., Global Value Chains and International Competition, Antitrust Bulletin, (56:1), 2011.

[8] Gans N.F., Issue and benefits of Global Supply Management.

[9] Kogut B., Designing Global Strategies: Profiting from Operational Flexibility. Sloan Management Review 27, 1985 
[10] Chopra S., Meindl P., Supply Chain Management. Strategy, Planning, and Operation, Fourth Edition, Pearson, New York, 2010

[11] Shah.Janath(2009),Supply Chain Management Text and Cases,Pearson,New Delhi

[12] Bowersox D., Closs D., Cooper M.B., Supply Chain Logistics Management, McGrawHill/Irwin, 2012.

[13] Kogut, B. (2003). Designing global strategies: Comparative and competitive valueadded Chains. In A. K Gupta \& D. E. Westney (Eds.) Smart globalization: Designing global strategies, creating global networks (pp. 13-37). San Francisco: Jossey Bass.

[14] The global supply chain Challenges for small and midsize enterprises White paper

[15] Fawcett, S.E., Birou, L. and Taylor, B.C. (1993), "Supporting global operations through logistics and purchasing”, International Journal of Physical Distribution \& Logistics Management, Vol. 23 No. 4, pp. 3-11.

[16] Koti,Kartikey(2014), Recital of supply chain management globally,International journal of core engineering and management,Vol.1,Pp-76-95

[17] COUSINS,PAUL.LAMMING,Rchard and Squire,Brain (2008) Strategic Supply Management Principles, Theories and Practice, Prentice hall.

[18] Bala,Kiran(2014), Supply Chain Management: Some Issues and Challenges - A Review, International Journal of Current Engineering and Technology, Vol.4, No.2,Pg 946-953

[19] Croom, S. Romano, P. and Giannakis, M. (2000) 'Supply Chain Management: An Analytical Framework for Critical Literature Review' European Journal of Purchasingand Supply Management, 6, 1, pp. 67-83

[20] Giannakis, M. \& Croom, S. M. (2000) 'Towards the development of a Supply ChainManagementParadigm: A Conceptual Framework' 9th International Annual IPSERA Conference, London Ontario, Canada.

[21] Yuehong,Xu and Erming,Xu"The Research on supply chain management of Chinese Enterprises in International operation After they entered WTO. White paper

[22] World Economic Forum (in collaboration with Bain \& Company and the World Bank). 2013. Enabling Trade: Valuing Growth Opportunities. Electronic access

[23] Beamon, B.M. (1998), "Supply chain design and analysis: models and methods", International Journal of Production Economics, Vol. 55 No. 3, pp. 281-94.

[24] Chen J., Sohal A. S., and Prajogo D. I.(2013). Supply Chain Operational Risk Mitigation: A Collaborative Approach, International Journal of Production Research, Vol. 51, No. 7, pp. 2186-2199.

[25] Creating competitive advantage through the supply chain insights on India,Council of supply chain management.

[26] ARNOLD, D. J. and QUELCH, J. A. "New Strategies in Emerging Markets". Sloan Management Review. Fall, 1998.

[27] http://noahgans.blogspot.com/2011/04/global-supply-chain-management.html 2011. 